\title{
Social Media Usage by Generation Z in Pre-trip Planning
}

\author{
Nyoman Indah Kusuma Dewi ${ }^{1, *}$, I Gusti Ketut Gede ${ }^{1}$, Anak Agung Ayu Mirah Kencanawati ${ }^{1}$, I Gusti Agung Bagus \\ Mataram $^{2}$ \\ ${ }^{1}$ Business Administration Department, ${ }^{2}$ Tourism Department \\ 1,2 Bali State Polytechnic \\ 1,2 Badung, Indonesia \\ *ikdewi@pnb.ac.id,igkgede@pnb.ac.id, mirahkencana@pnb.ac.id, mataram@pnb.ac.id
}

\begin{abstract}
Tourism marketing practices have gradually changed into more digital, thanks to the invention of the Internet and Communication Technology. It alters the notion of word of mouth to electronic word of mouth through social media applications. This study aims to investigate the Generation $Z$ perceptions toward the usage of social media and its features in the pre-trip planning decision-making process. Why Generation $Z$ ? The reason is this generation is raised in the Internet era and they never experienced non-Internet era. For the purpose of this research Generation $Z$ are those who were born in 1995-2000. The study applied a qualitative approach by administered questionnaires for data collection to Generation $Z$ and analysed employing the descriptive method. The results suggest that Generation $\mathbf{Z}$ used the Internet mostly for accessing photo and video sharing sites by $70 \%$ and $68 \%$ respectively. Generation $Z$ took into account mostly the content of social media, online review groups, and online recommendation from friends and relatives in the information search stage. Interestingly, they trust positive comments in the online travel community for granted and willing to share their travel experiences on community sites. The fake social media content is undeniably existing and future researchers should pay attention to this negative side of social media.
\end{abstract}

Keywords—social media, generation Z, e-WHOM, decisionmaking process

\section{INTRODUCTION}

Tourism marketing is currently using technology to approach its target market. The use of the Internet and various means of information and communication technology in the tourism marketing can increase the competitive power of companies in tourism sector. This is due to changes in activities, operations, and ways of communicating as well as changes in the way consumers search for information and decide to purchase tourism services and/or products [1]. Thus, consumer behaviour has changed by involving digital information in their decision-making process. Consumers are paying more attention to the importance of information and services on the Internet. The concept of word of mouth (WOM) in the search for opinions, testimonies, and comments about accommodation and tourist destinations has changed to online or electronic word of mouth (eWOM) [2-4]. One of the usage of communication technology in tourism marketing is the use of social media through several platforms such as Facebook, Twitter, Instagram, YouTube, Blogs, Snapchat, Tumblr, Reddit, and others as a means to communicate with consumers [5-7]. The impact of social media in the tourism industry has been evident as a reliable promotional tool to reach travellers [8]. Social media is a group of internet applications created based on the ideology and technology of Web 2.0, which facilitates the creation and exchange of content created by its users [9]. Social media is classified into the following types [912]: (1) Content communities: on this website, users can share content (for example BookCrossing, YouTube, Flicker, Pinterest, Instagram, etc.); (2) Social Network Sites (SNS's): are websites that allow people to create profiles with personal information, share the content with relatives and friends (for example Facebook, LinkedIn, etc.); (3) Virtual games/social world platforms: where users can be seen as avatars and interact with other users as in real life (for example online games and websites like Second Life); (4) Collaborative projects: where users can add, remove and change text-based content on this website (for example Wikipedia); and (5) Virtual communities: on this platform people can share information or content (for example Twitter, WhatsApp, Line), and have an opinion on a particular topic, can write a review (for example TripAdvisor, Virtual Tourist) or write a diary (personal blogs). In addition to being used to build social relations, social media is also considered as a source of information to make decisions in the purchase of goods and services. Social media is also used enormously as a marketing communication tool $[11,13]$ to reach customers. Social media users are mostly young people or known as Generation Z [14]. Although many researchers have a different categorizations of Generation Z, for the purpose of this study, Generation $\mathrm{Z}$ is those who were born in early 1995 to 2000 [14-16]. Generation $\mathrm{Z}$ grew up in the information technology boom in which the Internet is part of their life either for academic or social purposes. They have a high dependence on electronic media and digital technology in terms of deciding for traveling [17]. 
The impact of social media concerning tourism destination marketing has been widely studied $[8,18,19]$. The information deployments of a tourism destination are faster to reach travellers through social media platforms and could minimize cost [8]. Research of Dina and Sabou [18] found that young generation believes the information on social media and consider it to decide on a tourist destination. Similarly, Ly and Ly [19] revealed the significant influence of social media in the decision-making process. Additionally, social media as a tool to assist in deciding the tourist destination has been studied massively by academia to the name a few are [4,20-23]. Research by Tham et al [4] assured the destination image spread in social media as e-WOM has an impact on tourists' opinions of a destination. The study by Hua et al [20] confirmed the power of social media as a decision-making tool to select a destination. Social media and its content improve awareness of a tourist destination [21, 22]. In line with the previous researchers, Shyle and Hysi [23] point out that social media is a communication and marketing tool highly used by tourists to search destination information. Since only few researches take into account the Generation $\mathrm{Z}$ attitude towards social media usage in the decision-making process to determine the tourism destination (pre-trip) particularly in the Indonesian context, the author aims to explore this topic.

Regarding the gap of the research, thus the purpose of this study is to explore the role of social media for Generation $\mathrm{Z}$ tourists in the planning process of deciding on a touristic destination. In the pre-trip phase, social media involve in need recognition, information search, evaluation alternatives, and purchase decision [11]. The study was conducted in Badung Regency, Bali Province, Indonesia in which Internet literation amongst Generation $\mathrm{Z}$ is excessive. The data shows that in the last 3 months in 2019, the population aged over 5 years old in Badung Regency who accessed the Internet amounted to a $67.62 \%$ increase from $61.18 \%$ in 2018 [24].

\section{RESEARCH METHODS}

Qualitative research was conducted by distributing questionnaires to Generation $\mathrm{Z}$ tourists who travelled in five Tourism Villages in Badung Regency, namely Mengwi Tourism Village, Sangeh Tourism Village, Bongkasa Pertiwi Tourism Village, Pelaga Tourism Village, and Pangsan Tourism Village. The total number of respondents was 50 people with an allocation of 10 respondents for each tourism village. The reliable number of samples for a study with the unknown population should be more than 30 [25]. The sampling technique used in this study was purposive sampling. Primary data and secondary data were employed in this study. Data collection techniques were questionnaires and documentation. The questionnaire was closed and open questions with a Likert scale consisting of 4 categories. Each question was given a score starting at 1 for disagree, 2 for the less agree, 3 for agree, and 4 for strongly agree. The documentation technique was for supporting primary data from questionnaires to achieve data triangulation purposes [26]. Data were then analysed with descriptive statistical analysis techniques [25].

\section{RESULT AND DISCUSSION}

\section{A. Demography of Respondents}

From 50 respondents, $58 \%$ is male and $42 \%$ is female. While the age of respondents spread from 20 years to 21 years with a percentage of $10 \%$, and $90 \%$ respectively. Whereas, most of them still live with their family. The majority of Generation $\mathrm{Z}$ was using social media in form of Instagram (92\%), WhatsApp (66\%), Line (58\%), Facebook $(40 \%)$, Twitter (20\%), and YouTube (4\%). The findings show that Content Communities sites, Social Network Sites, and Virtual Communities sites are the most popular social media platforms amongst Generation Z.

\section{B. The Usage of the Internet}

Most Generation $\mathrm{Z}$ searched information of tourist destination spot via the Internet $(88 \%)$, followed by recommendations from friends and relatives $(31 \%)$, Television $(28 \%)$, Travel advertisements in magazines and newspapers $(8 \%)$, and information from travel agents and travel-related companies $(2 \%)$. This is confirmed with the characteristic of Generation $\mathrm{Z}$ as the first generation that has been exposed by the Internet during their upbringing that shapes their digital behaviour [27]. This illustrates how they trust the Internet more than other sources of information. This is also matched with the fact that they daily accessed the Internet (98\%), television (22\%), and radio (4\%). When using the internet to search and collect information regarding tourist destination, they utilized Photo Sharing Sites (70\%), Video Sharing Sites $(68 \%)$, Facebook (16\%), News Delivery Sites (6\%), Websites/blogs (44\%), Mobile Applications (2\%), and Collaborative Websites $(6 \%)$, as illustrated in Fig. 1. Photo Sharing Sites and Video Sharing Sites are the two main media they preferred the most. Generation $\mathrm{Z}$ is believed and influenced by photos or videos shared by other travellers, influencers, and travel vloggers on Instagram or YouTube [28]. Generation Z's perceptions can be changed and influenced by a post on Instagram which leads to their behavioural intentions during the pre-visitation phase [29].

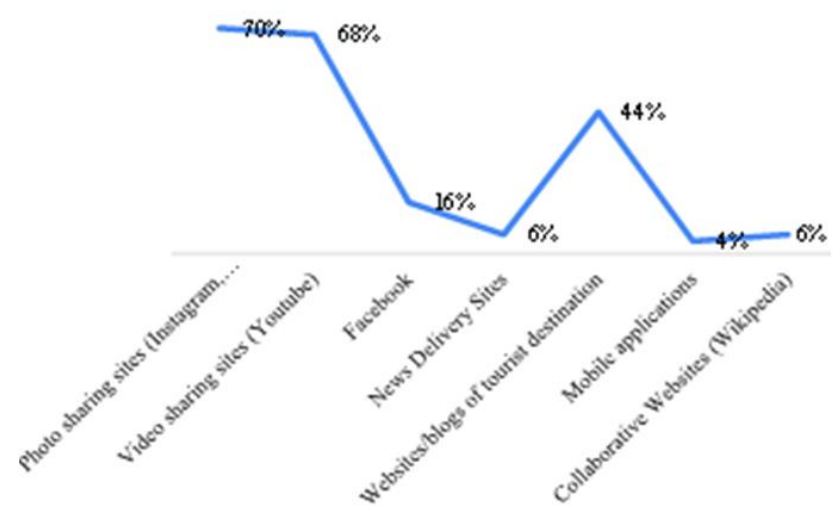

Fig. 1. The usage of internet. 
Video-Sharing Sites such as YouTube has evolved from social media tool into marketing communication tool [30]. Travel video vlogging consists of information, a profile of vlogger, and uploaded content composing destination image from where Generation $\mathrm{Z}$ seek for the information. e-WOM is through sharing testimonials, opinions, and comments of vloggers [2-4]. Accordingly, 98\% of Generation $\mathrm{Z}$ used a mobile phone to open social media, $82 \%$ to browse information on the Internet, $76 \%$ to surf the YouTube, $74 \%$ to send messages, and $68 \%$ to make a call. This finding approves the digital native characteristics of Generation $\mathrm{Z}$ that always relate to the digital environment [14].

\section{The Usage of Social Media}

In the information search phase, when collecting data on tourist destinations, Generation $\mathrm{Z}$ travellers consider the opinions of other social media users, online recommendations from friends and relatives, online opinions from the experts, and online reviews.

The findings of considering opinions of other social media users by Generation $\mathrm{Z}$ can be seen in Fig. 2 as follows:

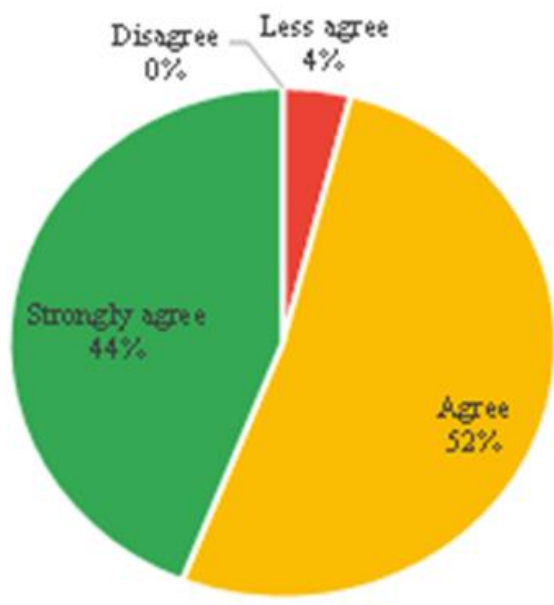

Fig. 2. Opinion of other social media users

About $96 \%$ of respondents agreed to take into account the opinions of other social media users in considering the selection of tourist destination areas and the remaining 4\% expressed disagreement. This reflects that the opinions of other social media users have a significant influence in making decisions process for selecting tourist destination in pre-trip planning [31,32]. In fact, Generation $\mathrm{Z}$ has more confidence in comments and posts from people they have not met personally than recommendations from the officials [14]. Social media is the first thing that Generation $\mathrm{Z}$ will rely on when they require data or information regarding tourist destinations by observing at photos, videos, comments, testimonials, opinions, and conversations in groups shared by other travellers. After comparing information on social media, alternative destinations are listed and then the final destination is selected after giving attention to other considerations such as budgeting.
Online recommendations from friends and relatives also have immense effects as shown in the following chart.

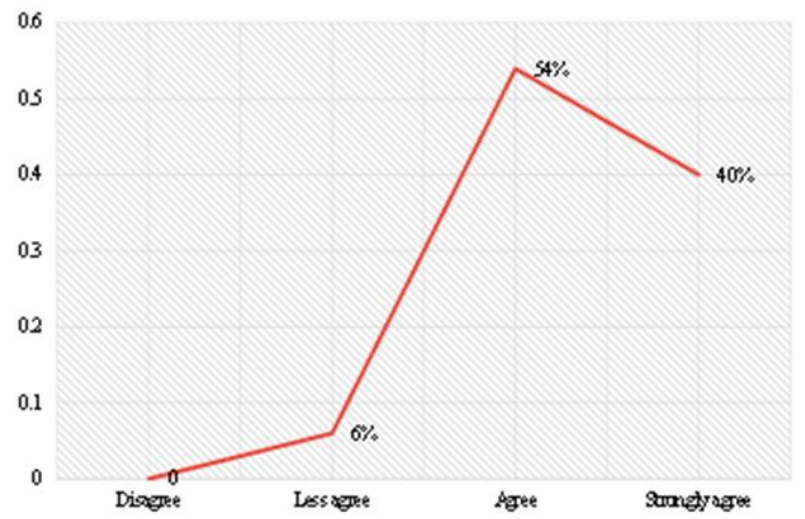

Fig. 3. Recommendation from friends and relatives

Despite belief only on social media reviews, online recommendations from friends and relatives also become an important consideration. The majority of the respondents of $94 \%$ (54\% agreed and 40\% absolutely agreed) rely on recommendations from friends and families by looking at their posts in social media. This is understandable because they trust an honest recommendation from people they know personally. Consumer's decision to purchase or experience product or service depends on the recommendation from family, friends, colleagues, and other consumers when dealing online [3].

Expert's online opinions have recognized as one source of information although not as significant as other social media users and recommendations from friends and relatives. Fig. 4 presents the findings of the influence of expert's opinions from Generation Z's point of view. It can be seen that $46 \%$ of respondents do not put attention to expert's opinions, meanwhile, $54 \%$ search for expert's opinions as a consideration.

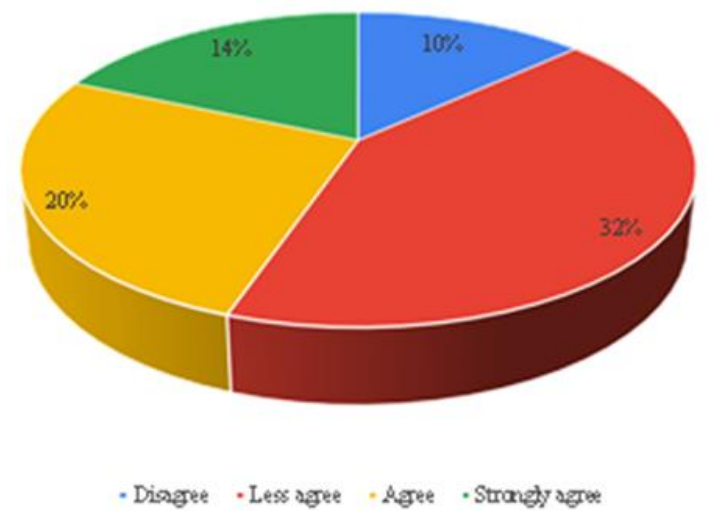

Fig. 4. Expert's opinions.

Online reviews (such as TripAdvisor) also play an important role when collecting data on tourist destinations, $96 \%$ of respondents usually search and read online reviews to 
get supportive and reliable information and compare it with other information from other sources to get the best alternatives before making a decision. Only $4 \%$ of respondents do not bother to check the online reviews. Fig. 5 demonstrates the role of online reviews.

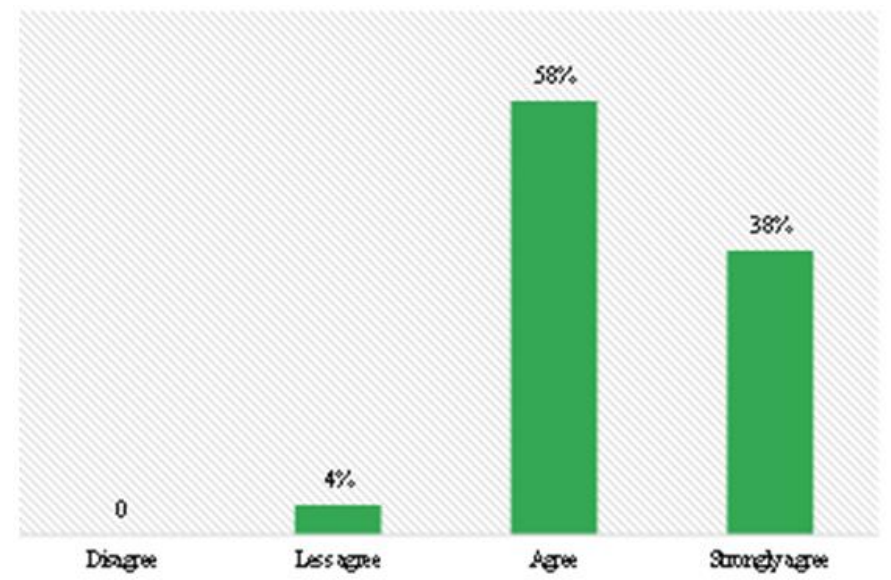

Fig. 5. Online reviews

The usage of social media in the information search phase on pre-trip is evident to a certain extend. Generation $\mathrm{Z}$ gathers information from different social media platforms intending to compile a wide array of data to be compared to get the best alternatives of choices.

\section{The Role of The Online Travel Community}

Community members will be more confident with the comments or advice of other members when looking for recommendations on tourist destinations. Generation $\mathrm{Z}$ travellers favour opinions and advice from peer recommendations in the online community [33,34]. Moreover, gathering the information from online travel communities more likely to bring benefit in terms of saving time to search and straight to the necessary information [35]. The findings in Fig. 6 suggest that $70 \%$ of respondents strongly agree and $10 \%$ agree that they trust the members. The rest of $20 \%$ do not trust the online community members.

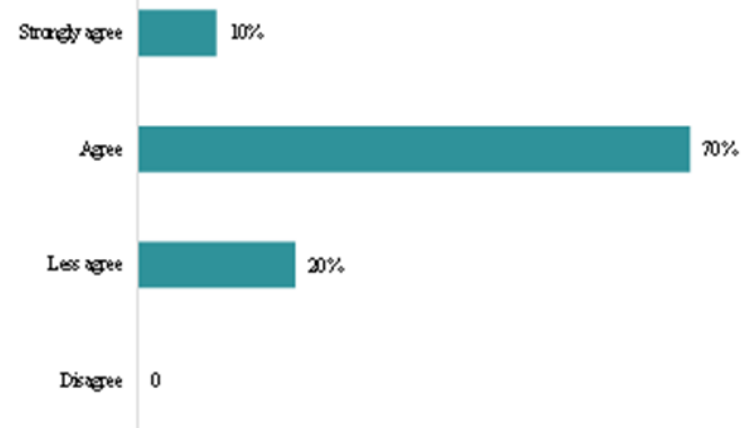

Fig. 6. Trust to online travel community advice.
Moreover, the community members felt they had a closer relationship with other community members even though they had never encountered personally, 92\% agreed and strongly agreed to this statement as can be seen in Fig. 7 [36]. This is the main characteristic of Generation $\mathrm{Z}$ that they were born in the Internet era and familiar to use it and make online friends for assisting and easing their daily life.

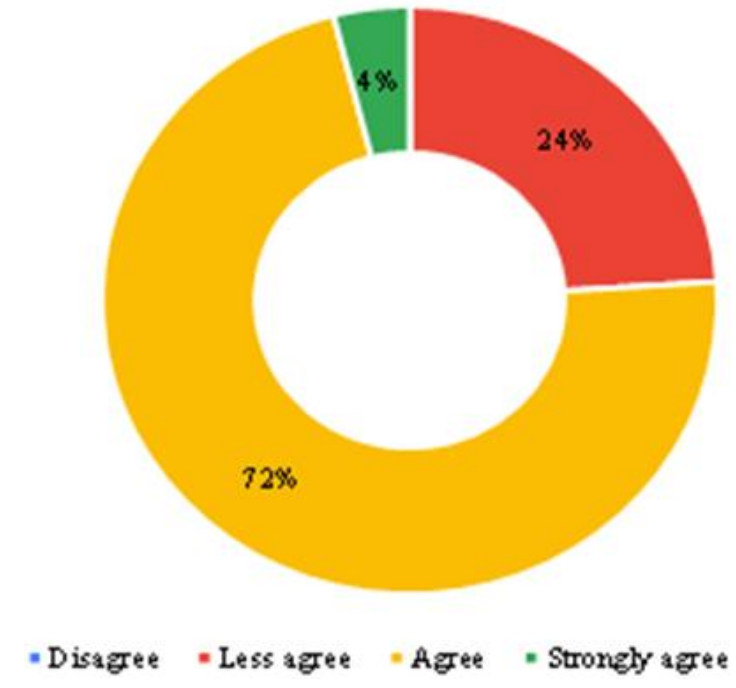

Fig. 7. Close relationship in online travel community.

More importantly, Generation $\mathrm{Z}$ is willing to upload personal experiences includes photos and videos related to tourist destinations because they trust and feel-close with the members of the online community since social media has become their place for socializing [37]. Fig. 8 shows that $54 \%$ strongly agree and $28 \%$ agree to share their travel experiences, meanwhile only $18 \%$ is unwilling and want to keep their privacy.

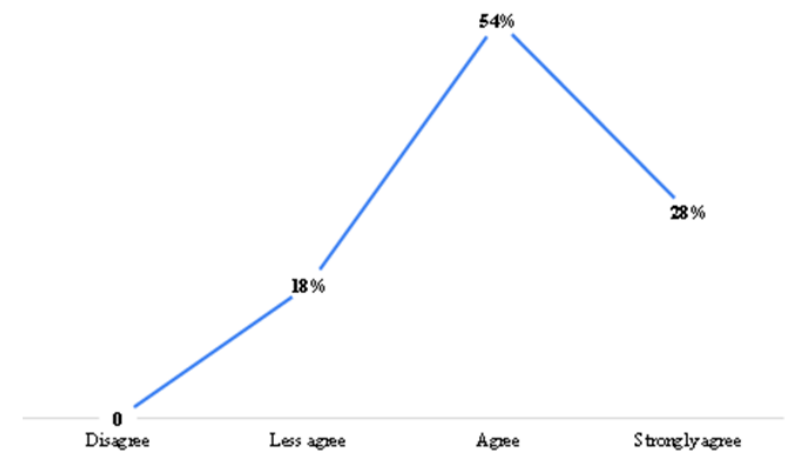

Fig. 8. Willingness to share experiences.

To sum up, the role of the online travel community is dominant for influencing the Generation $\mathrm{Z}$ decision-making process since friendship and socialization mostly take place in social media as part of their lifestyle. 


\section{E. Generation Z Pre-Trip Consideration}

Generation $\mathrm{Z}$ in the pre-trip decision-making process involves searching for positive comments regarding travel destinations, travel agents, accommodation, and culinary on social media. Findings reveal that $64 \%$ agree and $36 \%$ strongly agree that they are influenced by a positive comment on the travel destinations on social media.

In terms of choosing a travel agent, Generation $\mathrm{Z}$ person is affected by positive comments. The findings indicate that $10 \%$ expressed less agree, $66 \%$ agreed and $24 \%$ strongly agreed regarding this matter.

Similarly, the positive comments also become prominence consideration when choosing accommodation (6\% less agree, $70 \%$ agree and 24\% strongly agree) and culinary (4\% less agree, $64 \%$ agree, and $32 \%$ strongly agree) in pre-trip planning.

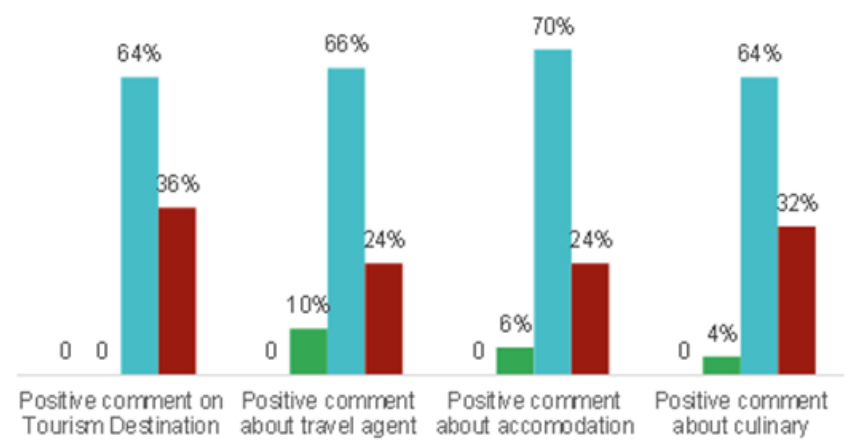

Fig. 9. Pre-trip consideration.

Positive comment unarguably influences Generation $\mathrm{Z}$ in pre-trip decision making. Compilation of information about tourism spots, accommodation, and travel agent have a major role to motivate Generation $\mathrm{Z}$ travellers. The best alternatives are composed and later decided which of them are suite and meet their planning.

\section{CONCLUSION}

Generation $\mathrm{Z}$ perceived social media and its various platforms as a reliable sources of information when selecting a travel destination. Hence the content is rich, diverse, and trustworthy. Generation $\mathrm{Z}$ used the Internet mostly for accessing photo and video sharing sites by $70 \%$ and $68 \%$ respectively. The rest is for Facebook, news delivery sites, official websites/blogs, mobile apps, and collaborative sites. Generation $\mathrm{Z}$ took into account mostly the content of social media, online review groups, and online recommendations from friends and relatives when looking for online recommendation before deciding the best alternative of a travel destination. Interestingly, they trust positive comments on the online travel community for granted. Generation $\mathrm{Z}$ is preferably and willing to share personal travel experiences on social media channels as their nature for socializing. Arguably, the massive content spreads in social media cannot be guaranteed to be all genuine. There a lot of fake accounts and misleading information that might affect the reliability and validity of the information. Future research should be done to investigate this fact.

\section{ACKNOWLEDGMENT}

This paper is a result of the Institutional Research Competitive Scheme funded by Bali State Polytechnic in 2020. Authors are humbly thanking the Director of Bali State Polytechnic and Centre of Research and Community Service and team for their support; without their contribution, this research would not be possible.

\section{REFERENCES}

[1] R. Law, D. Buhalis and C. Cobanoglu, "Progress on information and communication technologies in hospitality and tourism," International Journal of Contemporary Hospitality Management, vol. 26, issue 5, pp. 727-750, 2014.

[2] I. Bizirgiannia and P. Dionysopoulou, "The 2nd International Conference on Integrated Information, The influence of tourist trends of Youth Tourism through," Social Media (SM) \& Information and Communication Technologies (ICTs), Procedia - Social and Behavioral Sciences, vol. 73, pp. 652-660, 2013.

[3] A. Mukherjee and M. Nagabhushanam, "Role of social media in tourism marketing," International Journal of Science and Research (IJSR), vol. 5, issue 6, pp. 2026-2033, 2016.

[4] A. Tham, G. Croy and J. Mair, "Social media in destination choice: Distinctive electronic word-of-mouth dimensions," Journal of Travel \& Tourism Marketing, vol. 30, no. 1-2, pp. 144-155, 2013.

[5] N.L. Chan and B.D. Guillet, "Investigation of social media marketing How does the hotel industry in Hong Kong Perform in marketing on social media websites?" Journal of Travel \& Tourism Marketing, vol. 28, pp. 345-368, 2011

[6] R. Hanna, L. Crittenden and L. Victoria, "We're all connected: The power of the social media ecosystem," Business Horizons, vol. 54, pp. 265-273, 2011.

[7] M. Anderson and J. Jiang, Teens, social media \& technology [Online] Retrieved from: http://www.pewinternet.org/2018/05/31/teens-socialmedia-technology-2018/, 2018.

[8] D.R. Buted, N.S. Gillespie, J.B. Conti, B.A. Delgado, R.M.P Marasigan, S.K.A. Rubico and S.S. Felicen, "Effects of social media in the tourism industry of Batangas Province," Asia Pacific Journal of Multidisciplinary Research, vol, 2, no. 3, pp. 123-131, 2014.

[9] A.M. Kaplan and M. Haenlein, "Users of the world, unite! The challenges and opportunities of Social Media," Business Horizons, vol. 53, pp. 59-68, 2010

[10] K. Heinonen, "Consumer activity in social media: Manageria approaches to consumers' social media behavior," Journal of Consumer Behaviour, vol. 10, no. 6, pp. 356-364, 2011

[11] R. Minazzi, Social media impacts on travelers. Social media marketing in tourism and hospitality. New York: Springer, pp. 47-76, 2014

[12] A. Wilson, H. Murphy and J.C. Fierro, "Hospitality and travel the nature and implications of user-generated content," Cornell Hospitality Quarterly, vol. 53, no. 3, pp. 220-228, 2012.

[13] P. Kumar, V. Kumar and J.M. Mishra, "Social Media: A Tool for Tourism Marketing," International Research Journal of Business and Management, vol. 8, no. 11, pp. 1-6, 2015.

[14] C.K. Dimitriou and E. AbouElgheit, "Understanding Generation Z's social decision-making in tourism," Tourism and Hospitality Management, vol. 25, no. 2, pp. 311-334, 2019. 
[15] M. Ensari, "A study on the differences of entrepreneurship potential among generations," Research Journal of Business and Management, vol. 4, no. 1, pp. 52-62. 2017.

[16] A. Niemczyk, R. Seweryn and A. Smalec, " $Z$ generation in the international tourism market," Economic and Social Development: Book of Proceedings, Varazdin: Varazdin Development, pp. 123-132, 2019.

[17] B. Setiawan, N.L.P. Bean, N.L.P. Trisdyani, P.P. Adnyana, I.N. Adnyana, K. Wiweka and H.R. Wulandani, "The profile and behaviour of 'digital tourists' when making decisions concerning travelling case study: generation Z in South Jakarta," Advances in Research, vol. 17, no. 2, pp. 1-13, 2018.

[18] R. Dina and G. Sabou, "Influence of social media in choice of touristic destination,” Cactus Tourism Journal, vol. 3, no. 2, pp. 24-30, 2012.

[19] B. Ly and R. Ly, "Effect of Social Media in Tourism (Case in Cambodia)," Journal of Tourism \& Hospitality, vol. 9, no. 1, pp. 1-9, 2020.

[20] L.Y. Hua, T. Ramayah, T.A. Ping and C. Jun-Hwa (Jacky), "Social Media as a Tool to Help Select Tourism Destinations: The Case of Malaysia," Information Systems Management, vol 34, no. 3, pp. 265 279, 2017.

[21] S. Hudson and K. Thal, "The impact of social media on the consumer decision process: implications for tourism marketing," Journal of Travel \& Tourism Marketing, vol. 30, pp.156-160, 2013.

[22] H. Kasim, E. Abdulrahman, A. Furinto, and W. Kosasih, "Social network for the choice of tourist destination: attitude and behavioral intention," Management Science Letters, vol. 9, pp. 2415-2420, 2019.

[23] I. Shyle and V. Hysi, "Social Media and its Impact on Decision Making for Trip," European Journal of Interdisciplinary Studies, vol 1, no. 1, pp 8-15, 2015.

[24] Statistics of Bali Province, "Percentage of Population Aged 5 Years and Over Who Accessed of Information and Communications Technology Over the Last 3 Months by Regency/Municipality [Online]. Retrieved from: bali.bpb.go.id, 2019.

[25] U. Sekaran and R. Bougie, Research Methods for Business A SkillBuilding Approach. 7th ed., Chichester: John Wiley \& Sons Ltd., 2016.

[26] M. Saunders, P. Lewis and A. Thornhill, Research methods for business students. 6th ed. Edinburgh: Pearson Education Limited, 2012.
[27] G.P. Yadav and J. Rai, "The Generation $Z$ and their social media usage: a review and a research outline global," Journal of Enterprise Information System, vol. 9, no. 2, 2017.

[28] F. Magno and F. Cassia, "The impact of social media influencers in tourism," Anatolia, vol. 29, no. 2, pp. 288-290, 2018

[29] S. Shuqair and P. Cragg, "The immediate impact of Instagram posts on changing the viewers' perceptions towards travel destinations," Asia Pacific Journal of Advanced Business and Social Studies, vol. 3, no. 2, pp. 1-12, 2017.

[30] V.D. Trinh, and D.Y.L. Nguyen, "How to Change Perceived Destination Image Through Vlogging on Youtube," Proceedings of the 1st International Conference on Management Science 'DIGITAL DISRUPTION ERA: Challenges and Opportunities for Business Management', pp. 1-20, 2019.

[31] A. Pabel and B. Prideaux, "Social media use in pre-trip planning by tourists visiting a small regional leisure destination," Journal of Vacation Marketing, vol. 22, no. 4, pp. 335-348, 2016

[32] Z. Xiang and U. Gretzel, "Role of social media in online travel information search," Tourism Management, vol. 31 pp. 179-188, 2010

[33] C.C. Chiao and C.C. Yang, "The impact of recommendation sources on online purchase intentions: the moderating effects of gender and perceived risk," International Journal of Social, Behavioral, Educational, Economic, Business and Industrial Engineering, vol 4, no. 6, pp. 655658, 2010.

[34] L.V. Casaló, C. Flavián and M. Guinalíu, "Understanding the intention to follow the advice obtained in an online travel community," Computers in Human Behavior, vol. 27, pp. 622-633, 2011.

[35] I. Arsal, S. Backman, and E. Baldwin, "Influence of an Online Travel Community on Travel Decisions," Information and Communication Technologies in Tourism, pp. 82-93, 2008.

[36] K. Hur, T.T. Kim, O.M. Karatepe and G. Lee, "An exploration of the factors influencing social media continuance usage and information sharing intentions among Korean travellers," Tourism Management, vol. 63, pp. 170-178, 2017.

[37] A.M. Munar and J.K.S. Jacobsen, "Motivations for sharing tourism experiences through social media," Tourism Management, vol. 43, pp. 46-54, 2014. 